\title{
Effects of sun-curing, formic acid-treatment or microbial inoculation of timothy on urea metabolism in lactating dairy cows
}

\author{
D.R. Ouellet ${ }^{1,4}$, R. Berthiaume ${ }^{1}$, G.E. Lobley ${ }^{2}$, R. Martineau ${ }^{3}$ \\ and H. Lapierre ${ }^{1}$
}

\author{
${ }^{I}$ Dairy and Swine R\&D Centre, Agriculture and Agri-Food Canada, Lennoxville, Quebec, Canada \\ ${ }^{2}$ Rowett Research Institute, Scotland, UK \\ ${ }^{3}$ Departement of Animal Science, Université Laval, Québec, Canada
}

\begin{abstract}
Urea metabolism was estimated in dairy cows fed forage conserved as hay, formic acidtreated silage or microbial inoculated silage. Use of $\left[{ }^{15} \mathrm{~N}^{15} \mathrm{~N}\right]$ urea kinetics indicated that urea$\mathrm{N}$ production was greatest $(\mathrm{P}<0.05)$ with inoculated silage. Gut entry rate of urea-N was not affected by treatments. Urea-N recycled to ornithine cycle tended to be greater $(\mathrm{P}<0.08)$ when cows received inoculated silage compared to when fed acid-treated silage. The proportion of recycled urea-N lost in faeces was greater $(\mathrm{P}<0.05)$ when cows were fed forage conserved as hay as opposed to when fed inoculated silage. Overall, urea metabolism was similar between cows fed formic acid-treated silage or hay. Inoculated silage, however, increases urea production and recycling to the ornithine cycle.
\end{abstract}

KEY WORDS: urea, gastrointestinal tract, forage conservation, silage additives

\section{INTRODUCTION}

In ruminants, $\mathrm{N}$ exchanges between tissues are numerous and complex. Hepatic ureagenesis resulting from ammonia detoxification and amino acid catabolism is a major cross-road of these exchanges and is equivalent to 0.80 of the $\mathrm{N}$ digested in dairy cows (Lapierre et al., 2004). To increase the proportion of $\mathrm{N}$ intake transferred into milk, it is important to diminish inefficient use of $\mathrm{N}$. Therefore, the objective of this project was to determine the effect of the type of conservation of forage on urea kinetics, including whole body production,

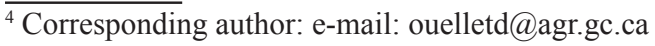


recycling to the gastro-intestinal tract (GIT) and proportions of this recycling used for anabolic purposes, reabsorbed as ammonia or lost in the faeces.

\section{MATERIAL AND METHODS}

\section{Animals, diets and design}

Six cows were used in a replicated $3 \times 3$ Latin square design to study the effect of three methods of conservation of timothy (Phleum pratense L.) on urea kinetics. Treatments were: 1. sun-cured hay (Hay: $48 \mathrm{~h}$ wilting), 2. formic acid-treated silage (Formic: $6 \mathrm{~L}$ of $85 \%$ formic acid per ton of fresh forage; $24 \mathrm{~h}$ wilting), or 3. microbial inoculated silage with Lactobacillus plantarum LPH-1 and Pediococcus cerevisiae PCH-3 (Inoculant: $1.25 \times 10^{11}$ total CFU per ton of fresh forage; $20 \mathrm{~h}$ wilting). Cows were fed in 12 equal meals per day of a diet with a ratio of 60.40 forage:concentrate $(14.5 \% \mathrm{CP}$; ground maize and soyabean meal based). The CP concentration of the forage averaged 10.1, 12.0 and $12.2 \%$, for Hay, Formic and Inoculant, respectively, likely due to a loss of leaves with the longer wilting period for the Hay. From d 16 to 22, a total collection of urine and faeces was performed. Cows were catheterized in one jugular vein on day 18 . On $\mathrm{d} 19$, cows were infused in the jugular vein with ${ }^{15} \mathrm{~N}^{15} \mathrm{~N}$-urea $(0.5 \mathrm{mmol} / \mathrm{h})$ for $72 \mathrm{~h}$ to estimate urea kinetics. On day 22, urine and faecal grab samples were collected at $9.00 \mathrm{~h}$. Enrichments in urine and faeces were determined as described by Lobley et al. (2000).

\section{Calculations and statistics}

Urea kinetics was calculated as described previously (Figure 1; Lobley et al., 2000). Urea production (urea entry rate - UER) is eliminated in urine (urea excreted in urine - UUE) or transferred to the GIT (gut entry rate - GER). The latter is hydrolysed in the lumen by bacteria and the $\mathrm{NH}_{3}$ released can undergo three fates: loss in faeces (urea faecal - UFE); re-entry the ornithine cycle (ROC), either directly or indirectly from catabolism of products of microbial or mammalian $\mathrm{NH}_{3}$ metabolism; or use for anabolic purposes, i.e. support of microbial protein synthesis (urea for anabolism - UA). Data were analysed using the MIXED procedure of SAS (SAS Institute, v. 8.01, 2000). Cow, period and square were treated as random, with treatment as a fixed factor. Pairwise comparisons between treatments were analysed using the Tukey-Kramer adjustment.

\section{RESULTS AND DISCUSSION}

Nitrogen intake, excreted in urine and secreted in milk averaged 295, 341 , and $351 \pm 24.9 ; 92,100$, and $113 \pm 6.5 ; 97,94$, and $100 \pm 10.1 \mathrm{~g} / \mathrm{d}$ for Hay, 


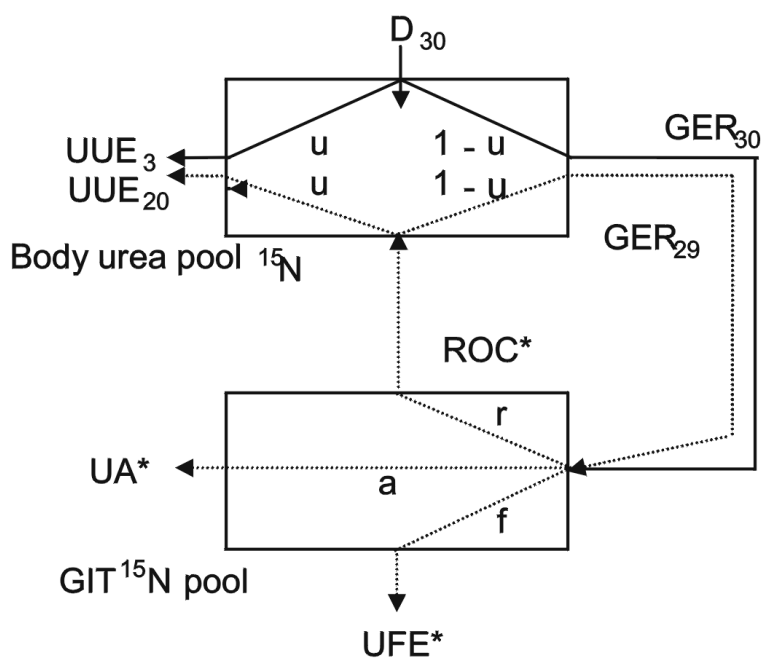

Figure 1. Schematic two-pool model with isotope flows based on infusion of $\left[{ }^{15} \mathrm{~N}^{15} \mathrm{~N}\right]$ urea. Fates of ${ }^{15} \mathrm{~N}$ direct from the dose are represented as (-) while fates from ${ }^{15} \mathrm{~N}$ liberated as $\mathrm{NH}_{3}$ in the gastrointestinal tract (GIT) are represented as $(\cdots)$. Movements of $\left[{ }^{5} \mathrm{~N}^{15} \mathrm{~N}\right]$ urea are given the subscript 30 while those of $\left[{ }^{14} \mathrm{~N}^{15} \mathrm{~N}\right]$ urea are given the subscript $29 . \mathrm{D}$, dose; UUE, urinary urea-N elimination; GER, GIT entry rate; ROC, return to ornithine cycle (mainly as ${ }^{15} \mathrm{NH}_{3}$ ); UA, urea- ${ }^{15} \mathrm{~N}$ utilized for anabolism (mainly as bacterial protein); UFE, urea- ${ }^{15} \mathrm{~N}$ to faecal excretion. Fraction transfers of GER to ROC*, UA* and UFE* are represented by $\mathrm{r}$, a, and $\mathrm{f}$, respectively, while $\mathrm{u}$ is the proportion of the dose eliminated in the urine (reproduced from Lobley et al., 2000)

Formic and Inoculant, respectively. Nitrogen intake was lowest $(\mathrm{P}<0.01)$ for Hay treatment, while urinary $\mathrm{N}$ was the highest $(\mathrm{P}<0.01)$ for Inoculant. Milk N was not affected by treatment. Nitrogen retention was higher $(\mathrm{P}<0.05)$ for cows fed Formic than those fed Hay (-6, 33 and $16 \pm 10.8 \mathrm{~g} / \mathrm{d}$ for Hay, Formic and Inoculant, respectively).

Production of urea-N was highest for Inoculant treatment $(\mathrm{P}<0.05)$, which also increased urinary urea- $\mathrm{N}$ loss $(\mathrm{P}=0.11)$, suggesting a large absorption of $\mathrm{N}$ as ammonia. Urea production was 0.94 of digested $\mathrm{N}$ for Hay, compared with 0.75 and 0.87 for Formic and Inoculant. Milk output:digested N averaged $0.53,0.42$ and 0.44 , respectively, indicating reliance on recycled urea to the gut. Nonetheless, urea GER was not affected by treatment although ROC tended to be higher $(\mathrm{P}=0.08)$ for Inoculant compared with Formic. In agreement with other studies, (Lobley et al., 2000; Archibeque et al., 2001), ROC seems to increase with $\mathrm{N}$ intake. There was no effect of treatment on UFE or UA. The proportion of urea-N excreted in the urine or in the GIT relative to UER was not affected by treatment ( 0.29 and 0.71 , respectively) nor were the proportions of GER that returned to ornithine cycle or to anabolism. Overall 0.46 of GER was transferred to anabolic pathways. 
Table 1. Effect of forage conservation on urea-N metabolism ${ }^{1}$

\begin{tabular}{lcccc}
\hline \multirow{2}{*}{ Urea kinetic variables, g urea-N/d } & \multicolumn{3}{c}{ Treatment $^{2}$} & \multirow{2}{*}{ SEM } \\
\cline { 2 - 4 } & Hay & Formic & Inoculant & \\
\hline Production (UER) & $172.3^{\mathrm{A}}$ & $170.6^{\mathrm{A}}$ & $200.0^{\mathrm{B}}$ & 7.05 \\
Entry to GIT (GER) & 123.4 & 121.6 & 140.4 & 8.23 \\
Urinary urea excretion (UUE) & 48.9 & 48.9 & 59.6 & 3.66 \\
Return to ornithine cycle (ROC) & $54.2^{\mathrm{a}, \mathrm{b}}$ & $53.2^{\mathrm{a}}$ & $62.7^{\mathrm{b}}$ & 2.93 \\
Losses to faeces (UFE) & 14.2 & 12.2 & 13.6 & 1.00 \\
Re-use for anabolism (UA) & 55.0 & 56.2 & 64.1 & 5.38 \\
Fractional transfer & & & & \\
$\quad$ UER to urine (u) & 0.283 & 0.287 & 0.298 & 0.023 \\
$\quad$ UER to GIT (1 - u) & 0.717 & 0.713 & 0.702 & 0.023 \\
$\quad$ GER to ROC (r) & 0.439 & 0.438 & 0.448 & 0.014 \\
$\quad$ GER to faeces (f) & $0.114^{\mathrm{a}}$ & $0.102^{\mathrm{a}, \mathrm{b}}$ & $0.095^{\mathrm{b}}$ & 0.005 \\
GER to UA (a) & 0.447 & 0.460 & 0.458 & 0.017 \\
\hline
\end{tabular}

${ }_{1}^{1}$ abbreviations were defined in the Material and methods section

${ }^{2}$ different letters in a row show differences among treatments: ${ }^{\mathrm{A}, \mathrm{B}} \mathrm{P}<0.05$; $^{\mathrm{a}, \mathrm{b}}-\mathrm{P}<0.10$

\section{CONCLUSIONS}

Across all treatments, urea recycling to the GIT and conversion to anabolic products was necessary to support milk protein output; recycled urea-N used for anabolic purposes represented 0.57-0.64 of milk protein output. Despite the fact that Inoculant addition to silage did lead to increased urea production (probably from increased ammonia absorption) and urinary loss compared with the Formic silage, urea recycled to the GIT was greater and represented a larger proportion of digested $\mathrm{N}$. This partly counterbalanced the increased urea production with as a result no effect on milk performance. The large urea recycling to the GIT relative to production, averaging 0.71 across treatments, helps to maintain good animal performance although total $\mathrm{N}$ intake was low.

\section{REFERENCES}

Archibeque S.L., Burns J.C., Huntington G.B., 2001. Urea flux in beef steers: Effects of forage species and nitrogen fertilization. J. Anim. Sci. 79, 1937-1943

Lapierre H., Raggio G., Berthiaume R., Thivierge M.C., Pacheco D., Dubreuil P., Lobley G.E., 2004. The route of absorbed nitrogen into milk protein. Anim. Sci. (submitted)

Lobley G.E., Bremner D.M., Zuur G., 2000. Effects of diet quality on urea fates in sheep as assessed by refined, non-invasive $\left[{ }^{15} \mathrm{~N}^{15} \mathrm{~N}\right]$ urea kinetics. Brit. J. Nutr. 84, 459-468 